\title{
Many Happy Returns? The Pro-Bowl, Mega-events, and Tourism in Hawaii
}

By

Robert Baumann and Victor Matheson

August 2015

\section{COLLEGE OF THE HOLY CROSS, DEPARTMENT OF ECONOMICS FACULTY RESEARCH SERIES, PAPER NO. 15-05*}

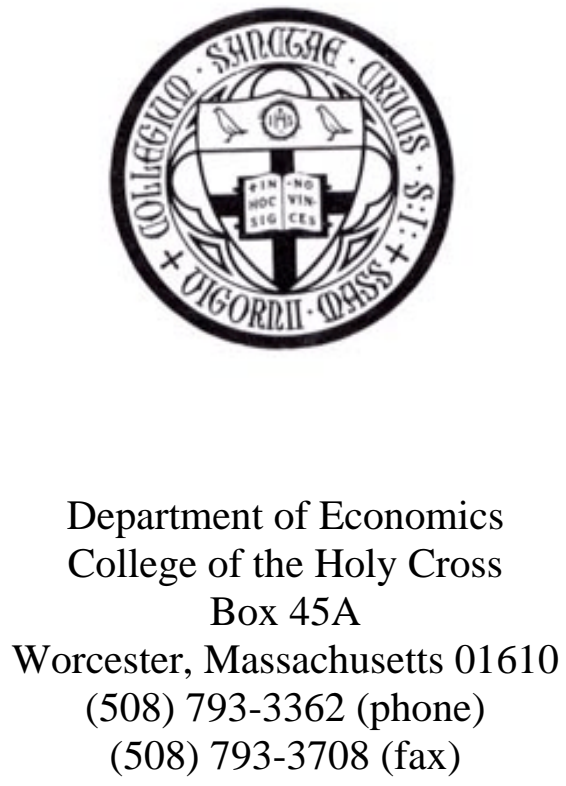

http://www.holycross.edu/departments/economics/website

*All papers in the Holy Cross Working Paper Series should be considered draft versions subject to future revision. Comments and suggestions are welcome. 


\title{
Many Happy Returns? The Pro-Bowl, Mega-events, and Tourism in Hawaii
}

\author{
by \\ Robert Baumann ${ }^{\dagger}$ \\ College of the Holy Cross \\ and \\ Victor A. Matheson ${ }^{\dagger \dagger}$ \\ College of the Holy Cross
}

August 2015

\begin{abstract}
:
We use daily airplane arrival data from 2004 to 2015 from Hawaii’s Department of Business, Economic Development, and Tourism to determine the net change in arrivals around a variety of sporting events. We find only one event generates a positive and significant net impact on arrivals: the Honolulu Marathon, which generates roughly 3,900 additional arrivals. No other sporting events result in a measurable increase in tourist arrivals including, notably, the NFL's Pro Bowl, which receives a large subsidy from the state's tourism authority.
\end{abstract}

JEL Classification Codes: Z28, O18, R53

Keywords: sports, stadiums, franchises, impact analysis, mega-event, tourism

\footnotetext{
${ }^{\dagger}$ Robert W. Baumann, Department of Economics, Box 192A, College of the Holy Cross, Worcester, MA 01610-2395 USA, 508-793-3879 (phone), 508-793-3708 (fax), rbaumann@holycross.edu

${ }^{+\dagger}$ Victor A. Matheson, Department of Economics, Box 157A, College of the Holy Cross, Worcester, MA 01610-2395 USA, 508-793-2649 (phone), 508-793-3708 (fax), vmatheso@holycross.edu
} 


\section{Introduction}

Sports boosters often make the claim that major sporting events bring large economic benefits to host communities by claiming these events produce an influx of tourists. Economists, on the other hand, suggest that most sports fans at a given event are typically local residents who are spending money as a spectator rather than elsewhere in the local economy. Furthermore, any fans who come from outside the region may be displacing other tourists or are casual visitors who would have come to the area anyway and just happen to include a sporting event in their travels.

This paper examines tourism patterns in Hawaii over the past decade to determine whether major sporting events increase visitors to the state. Hawaii provides an ideal setting for studying tourism as its remote island location results in precise visitor arrival data. In addition, Hawaii’s economy is strongly rooted in tourism with nearly 20 percent of workers in the state employed in the tourism sector or related fields, a figure second only to Nevada among the states (Bureau of Labor Statistics). Finally, this topic has important public finance implications. The Hawaii Tourism Authority (HTA), the state agency charged with promoting tourism, has a budget of over $\$ 70$ million. Some of these funds are used to promote spectator sports, such as the National Football League's all-star game, the Pro Bowl.

Previous scholarly work has examined tourism patterns in Hawaii, and in many ways this paper is similar to Baumann, Matheson, and Muroi (2009), which also examines tourist arrivals in Hawaii around sporting events. Using data from 2004 to 2008, Baumann, Matheson, and Muroi (2009) find the Pro Bowl resulted in 5,596 to 6,726 new net arrivals while the Honolulu Marathon increased visitors to the state by 
2,183 to 6,519 arrivals. Since that paper, the debate over the Hawaii's subsidy to the Pro Bowl has grown substantially. One impetus is the Pro Bowl's location. In each year between 1980 and 2009 the Pro Bowl was played in Aloha Stadium in Honolulu. Since 2009, the game has been moved out of Hawaii twice to the location of that year's Super Bowl: Miami Gardens, FL in 2010 and Glendale, AZ in 2014. While the game returns to Hawaii in 2016, there is currently no location for the 2017 Pro Bowl, and it is possible the NFL will stage the game abroad. ${ }^{1}$ Meanwhile, the Pro Bowl commands the highest spectator sport expenditure of the HTA, and its internal economic impact estimates for hosting the Pro Bowl have exploded.

This paper improves on Baumann, Matheson, and Muroi (2009) by exploiting the changes in the Pro Bowl's location to better identify to net impact of hosting the game. In addition, our estimates also provide an opportunity to examine the methodology of the HTA's economic impact statements, which have increased rapidly despite reported reductions in attendance at the game. We find the Pro Bowl does not have a statistically significant impact on arrivals to Hawaii. This finding questions the wisdom of public subsidies for the game. Among the other sporting events that we test, the Honolulu Marathon has the largest impact on arrivals. In the week leading up to the Honolulu Marathon, arrivals increase by roughly 3,900 visitors, which is a 2.5 percent increase.

\section{The History of the Pro Bowl}

The Pro Bowl is an event that dates back to as early as 1939. Officially designated the "Pro Bowl" in 1951, it became an annual event held in Los Angeles. In 1973, the

\footnotetext{
1 See Marvez, Alex. "NFL considering Brazil as host for 2017 Pro Bowl.” Fox Sports. Posted March 23, 2015. Accessed July 29, 2015.
} 
event began to change venues each year until 1980 when the game was given a semipermanent home in Hawaii. Between 1980 and 2009 it was played every year at Aloha Stadium in Honolulu, typically the week after the Super Bowl in late January or early February. In 2010, the NFL moved the game away from Hawaii for the first time in three decades, playing the game in Miami Gardens, the same host site as that season's Super Bowl. In the same year, the league changed the timing of the game to the week between the NFL's conference finals and the Super Bowl. The game returned to Aloha Stadium from 2011 through 2014, but the league kept the game in the week before the Super Bowl. In 2015, the game moved out of Hawaii to again be played at the same site as the Super Bowl in Glendale, Arizona. The game returns to Hawaii in 2016, and future Pro Bowls have yet to be scheduled.

The Pro Bowl has had mixed success as a sporting event. The NFL has recently considered dropping the game in response to falling television ratings and the perception that players do not treat the game seriously. The 12.2 million television viewers the event drew in 2013 was a fraction of 108.7 million viewers for the Super Bowl and also well under the 34.7 million viewers that the average NFL playoff game attracted that year (Sports Media Watch, 2013). Indeed, the Pro Bowl's television audience was lower than the typical regular season NFL game despite the fact that a majority of regular season games are not broadcasted to a full national audience. This distinction makes the Pro Bowl unique among major American professional all-star games, which typically draw a larger viewership than an average regular season game (Fletcher, 2010).

However, it is hard to characterize 12.2 million viewers as a ratings failure. Table 1 lists the American television ratings of the Pro Bowl and other major sporting events in 
2013. The Pro Bowl outdrew both Major League Baseball’s (MLB) and the National Basketball Association’s (NBA) All-Star Games. In fact, excluding other NFL games, in 2013 the Pro Bowl was among the 30 most-watched sporting events in the US, and its ratings that year exceeded those of every hockey game, soccer match, or tennis match among US viewers. Among the major American professional sports excluding the NFL, only World Series and NBA Finals games topped the Pro Bowl in ratings during 2013. The Pro Bowl also attracts a large live attendance crowd of roughly 50,000 fans each year.

\section{Sports Subsidies and Economic Impact}

The prominence of the Pro Bowl is one reason the HTA regularly pursues hosting the event in Hawaii. The Authority's annual budget is funded by a transient accommodations (hotels, condo rentals, etc.) tax, of which roughly two-thirds is dedicated to direct advertising and outreach. A portion of the remainder subsidizes various cultural festivals and sporting events. Table 2 summarizes HTA expenditures on events in 2013. In 2013 a total of $\$ 7.6$ million dollars was allocated to 20 cultural and 14 sporting events across Hawaii's six major islands. These events include a variety of native Hawaiian programs, wine, coffee, and film festivals, and a range of sporting events including college basketball tournaments, professional golf events, college football's Sheraton Hawaii Bowl, the Ironman World Championship, several water sports events, and the NFL's Pro Bowl (Hawaii Tourism Authority, 2014). For the right to host the 2014 Pro Bowl, the HTA paid the NFL \$4,000,000 and covered \$152,000 in game management costs (a figure rising to $\$ 5,000,000$ plus expenses in 2016) while the league 
keeps the revenue generated by ticket sales and media rights (Lewis, 2014). In other words, the Pro Bowl consumes more of the Hawaii Tourism Authority's annual budget than all of the organization's other subsidized events combined while allowing the NFL to keep all of the direct revenue associated with the game.

Indeed, the multi-million dollar subsidy received by the Pro Bowl has come under fire. In 2011, then-governor Neil Abercrombie stated it was "so stupid [the state would] do things like give 4 million bucks to a $\$ 9$ billion football industry and not give any money to children. You've got this spectacle of these multimillionaires and billionaires out there arguing about how they're going to divide it up, and then they come and ask us to bribe them with $\$ 4$ million to have a scrimmage out here in paradise. We've got to get our values straight and our priorities straight” (Associated Press, 2011).

The HTA defends its subsidy of the Pro Bowl by claiming that the television viewership provides advertising for the state and the event generates a boom in visitors and tourism spending. Unfortunately, there are several reasons to be skeptical of the HTA's economic impact estimates, which are summarized in Table 3. Between 2007 and 2013, the Pro Bowl experienced declining attendance and significantly fewer out-of-state visitors leading to stagnant or falling visitor spending estimates. This loss in the number of visitors is somewhat compensated by an estimated 33\% increase in per visitor spending. This large increase in per visitor spending over a short period of time alone raises concerns about the accuracy of the HTA's spending estimates, but the agency's 2014 figures are the most questionable. The HTA reported that the 2014 Pro Bowl experienced another 13 percent increase per visitor spending and the number of "visitors" to the Pro Bowl rose from 18,873 in 2012 to 47,270 in 2014. The 2014 economic impact 
study also reported \$15.9 million production costs and events as well as \$200 million in “media value” (Shankman, 2014).

The HTA’s 2014 economic impact study falls prey to several common errors. The first problem is that the 2014 study counts all fans at the game as “visitors" while previous studies only count people from outside the state who attended the game. The inclusion of local residents ignores the "substitution effect” of spending. By spending money at the game, local residents must substitute less spending elsewhere in the local economy. Put another way, a Hawaiian that buys a Pro Bowl ticket does not increase total spending in the state’s economy but rather shifts it from one sector to another.

Furthermore, it is highly unlikely that the average spending per spectator would increase if local residents, whose spending would typically be limited to one day and would not generally include things like rental cars or accommodations, are included. Even if locals are improperly included in an economic impact statement, their consumption patterns are radically different compared to out-of-state tourists. The inclusion of production costs and events is also potentially improper, especially if the production is done by businesses or imported labor brought in especially for the game. If so, this spending, if it does in fact occur, doesn’t fully accrue to Hawaiians and shouldn’t be counted as a benefit to the state.

A \$200 million advertising benefit is similarly suspect. Typically advertising benefits are estimated by calculating the amount of time during a sports telecast the host city is mentioned and valuing those mentions at the advertising rates that apply during the broadcast. Similarly, mentions of the city in news reports in other media outlets are tallied up and a similar valuation is applied. The problems with this estimate of value are 
numerous. First, most cities and states simply don't believe that advertising benefits, even when large, lead to a marginal increase in tourism that justifies the expenses of hosting. This is evident in the advertising budget of the HTA, who spends less than $\$ 50$ million per year on direct advertising despite Hawaii having the second most tourism-based economy in the country. In addition, equating media mentions to advertising value suggests that seeing Honolulu in a background shot for 30 seconds has the same value as a targeted 30-second television commercial. Furthermore, applying the same value of advertising to an entire game assumes that the advertising effect of seeing the host city during the game does not suffer from declining marginal utility of the advertising power.

While advertising benefits to mega-events may exist, two caveats must be mentioned. First, mega-events may be associated with negative publicity. For example, the blackout during the 2013 Super Bowl may have cast the host city, New Orleans, in a bad light. For example, if the city can't keep the lights on during their biggest event of the year, then what sort of place is it to visit or do business with the rest of the year? Similarly, the international reputations Munich and Atlanta were tarnished by the terrorist events that occurred during the Olympics held in each city, and allegations of bribery and corruption associated with Winter Olympics in Sochi and Salt Lake City as well as FIFA World Cups in Russia and Qatar have hurt those regions’ reputations.

Second, even events that go off perfectly may not generate future tourism to the host. Tourism relies heavily on word-of-mouth advertising as vacationers return and tell others about their trip, which can impact the decision-making of future travelers. When visitors to a mega-event relate their experiences, the discussion of the trip may focus on the sporting contest rather than the host city. Thus, the word-of-mouth advertising from a 
visitor to the 2012 Summer Olympics in London may be more likely to generate tourism for future Olympic games rather than enhance London's reputation as a vacation spot (Zimbalist, 2015).

\section{Past research}

Hawaii is not alone in producing large, positive estimates of sports-related tourism spending. In comparison, academic studies of mega-events either fail to find any increase in measurable economic activity associated with the event (Porter, 1999; Baade and Matheson, 2001, 2004, 2006, Coates and Humphreys, 2002; Hagn and Maennig, 2008, 2009; Jasmand and Maennig, 2008; and Baade, Baumann, and Matheson, 2008), or find increases that are a fraction of those claimed by boosters (Coates, 2006; Coates and Depken, 2006; and Baumann, Engelhardt, and Matheson, 2012).

Studies focusing on tourism are similarly negative. Ritchie and Smith (1991) find that while the name recognition of Calgary rose significantly as a result of the 1988 Winter Olympics, the boost was short-lived. Similarly, Tieglund (1999) shows that 40 percent of the full-service hotels in Lillehammer went bankrupt after the 1994 Winter Olympic Games. Lavoie and Rodriguez (2005) find that NHL games have only minimal effects on hotel occupancy rates on host cities. Peeters, Matheson and Szymanski (2014) and Fourie and Santana-Gallego (2015) examine tourist arrivals into South Africa during the 2010 World Cup. Both studies find a significant increase in arrivals, particularly from countries with teams participating in the event. However, the net increase in tourism of between 100,000 to 200,000 additional visitors is at most half of the predicted numbers prior to the event, and not a sufficient number to justify the billions of dollars spent on 
new stadiums for the tournament. Data on tourist arrivals for other South African sports events are similarly unencouraging (Fourie and Santana-Gallego, 2011). Finally, as mentioned previously, Baumann, Matheson and Muroi (2009) examine tourist arrivals in Hawaii finding statistically significant increases in tourism associated with the Pro Bowl (5,596 to 6,726 net new arrivals), Honolulu Marathon (2,183 to 6,519 additional arrivals), and Ironman Triathlon (1,880 and 3,583 arrivals). However, in the case of the Pro Bowl, the demonstrated increased is a fraction of the estimates in HTA economic impact studies.

\section{The Data}

This paper estimates the impact on airport arrivals of the Pro Bowl, Hawaii Bowl, two professional golf events, Honolulu Marathon, and Ironman Triathlon between January $3^{\text {rd }}$, 2004 to May $31^{\text {st }}$, 2015. Each of these events is publicized across the United States, and in some cases, all over the globe. In addition, most of these events are partially funded by the HTA, which reflects the HTA's belief that these events encourage Hawaiian tourism.

Analyzing events that occur regularly in the same area and time of the year is problematic. In some cases exogenous changes in sports can be used to identify event impact. For example, Coates and Humphreys (2002) and Baade and Matheson (2001; 2006) examine the effects of all-star games and post-season play in American professional sports. These events typically take place in different cities each year either by design or due to the random nature of which teams qualify for the post-season. Thus, the impact of an event can be estimated by examining a local economy in a year that an 
event is held in comparison with another year in which when the event is played elsewhere. Similarly, Coates (2011), Coates and Depken (2006) and Baade, Baumann, and Matheson (2008) examine monthly taxable sales data and rely on differences in the numbers or types of games played during specific months to estimate the impact of major sporting events on tax receipts.

Because the major sporting events in Hawaii typically occur in the same month during every year, neither annual nor monthly data are sufficient to tease out the effect of the games. The daily airplane arrival data used in this study and Baumann, Matheson, and Muroi (2009), in part, corrects for this deficiency. However, if the events regularly occur during the same part of the year, the results may be capturing seasonal effects rather the effects of the event. Fortunately the change in timing of the Pro Bowl as well as its absence twice during our sample frame reduces the possibility of this occurring.

Hawaii is a unique location to estimate economic impact since its remote location forces the majority of visitors to arrive by plane. In addition, Hawaii’s Department of Business, Economic Development, and Tourism provides daily arrival data at all Hawaiian airports. This allows us to estimate event impact by comparing actual arrival data leading up to the event to our prediction of arrivals based on the rest of the data. The use of daily data in economic impact analyses is rare out of necessity; most data sources aggregate data over longer time periods which forces researchers to identify any impact using monthly, or in some cases, annual data. In order to analyze the events in this study, daily data are a necessity since these events are typically held at the same times each year. However, a drawback of arrival data is that our estimate of impact is measured in extra arrivals rather than the dollars that they spend. 
Table 4 lists the events and their corresponding dates. We include two professional golf events: Hyundai Tournament of Champions ${ }^{2}$ and Sony Open. In general, these events are held at the same time each year, e.g. the Honolulu Marathon is held on the second Sunday of each December throughout our sample frame. However, there are some notable exceptions like the Pro Bowl which has shifted from early February to late January and, in some years, was not held in Hawaii. The Hawaii Bowl is typically held on Christmas Eve, which means our empirical analysis will not be able to distinguish between those arriving for the game and those arriving for the Christmas holiday.

Figures 1, 2, and 3 illustrate the average arrivals for each day of the week, month, and year, respectively. While the average number of arrivals during our sample frame is about 22,817, these figures show there is significant variation across days, months, and years. For example, average arrivals are highest during weekends and summer months. In addition, arrivals decreased during the most recent recession and have since rebounded to even higher levels.

\section{Model}

Our empirical strategy compares the actual arrival data leading up to the event with an estimate of arrivals for a given day of the week, month, and year. Box and Tiao (1975) provides an approach to estimate the marginal effect on arrivals of each event. Specifically, we model daily airport arrival data using an ARIMA process with interventions. This is a common approach in the analysis of economic impact in sports,

\footnotetext{
${ }^{2}$ Due to changing sponsorship, this event has also been called Hyundai Tournament of Champions (2011 to 2015), SBS Championship (2010), Mercedes-Benz Championship (2007 to 2009), and Mercedes Championships (2004 to 2006).
} 
e.g. Schmidt and Berri (2002), Matheson (2006), and Baumann, Matheson, and Muroi (2009). In addition to the autoregressive (AR), moving average (MA), and intervention terms, we also include dummy variables for each day of the week, month, and year to mitigate the variation illustrated in Figures 1 through 3. The ARIMA $(P, I, Q)$ model is $z_{t}=\alpha+\sum_{p=1}^{P} \phi_{p} z_{t-p}+\sum_{q=1}^{Q} \theta_{q} \varepsilon_{t-q}+\sum_{d=1}^{6} \beta_{d}$ day $_{d}+\sum_{m=1}^{11} \alpha_{m}$ month $_{m}+\sum_{n=2005}^{2015} \lambda_{n}$ year $_{n}+\sum_{s=1}^{S} \delta_{s}$ event $_{s}+\varepsilon_{t}$, where day $_{d}$, month $_{m}$, and year ${ }_{n}$, are dummy variables for all but one day, month, and year in the sample. In addition, $z_{t-p}$ represents the AR terms and $\varepsilon_{t-q}$ represents the MA terms. Finally, the events in Table 1 are the intervention terms and represented by a vector of dichotomous variables in event . $^{\text {. }}$

Because we use daily data, we have to consider the timing of arrivals in anticipation of each event. Hawaii is likely too remote for travelers to arrive the day of the event, but it is unclear how early travelers will come if any of our events are the motivation for their trip. It is plausible travelers arrive several days before the event in order to enjoy Hawaii's many amenities. For this reason, we model event $_{s}$ as a series of dichotomous variables for each of the seven days leading up to the event. The professional golf events in our analysis last four days, so we start counting from the final day.

Before estimating the model, we check whether the arrival data have unit roots using three tests: the augmented and generalized least squares versions of the original Dickey and Fuller tests (1979, 1981), Phillips and Perron (1988), and Kwiatkowski, Phillips, Schmidt, and Shin (1992). Since we include dichotomous variables for day of the week, month, and year in our empirical model, we perform these tests on the residual 
arrivals after accounting for these time variables. Specifically, we regress arrivals on the full set of time dummy variables using ordinary least squares and perform the unit root tests on the residuals of this estimation. Figures 4 and 5 plot daily arrivals and residual daily arrivals, respectively.

Table 5 presents the results of the unit root tests, all of which suggest that residual arrivals do not have a unit root. This is not surprising given the plot of residual arrivals at Figure 4, which implies a stationary series. One complication with these tests is choosing the number of lags, which are intended to mitigate serial correlation in the unit root tests. Fortunately, all of the unit root tests are robust to the number of lags.

Table 6 provides the estimation results. The Akaike Information Criterion (AIC), which is used to specify the number of the autoregressive $(P)$ and moving average $(Q)$ terms, sets $P=8$ and $Q=0$ but the estimates on our intervention terms are largely unaffected by the specification of $P$ and $Q$. In general, the Honolulu Marathon is the only event to exhibit a positive and statistically significant impact on daily arrivals. The bump in arrivals is most prominent four and five days prior to the event, which increases arrivals by roughly 1,000 people each day. There are also positive and statistically significant increases two, six, and seven days prior to the event. The sum of the statistically significant estimates suggests that the event brings an extra 3,900 arrivals in the week leading up to the Honolulu Marathon, which is roughly a 2.5 percent increase over an average week in December. It is worth noting that this figure lies right in the middle of the Baumann, Matheson, and Muroi’s (2009) range of estimates for the increase in visitors due to the Honolulu Marathon. 
None of the other events in our study, which includes the Pro Bowl, two professional golf events, Ironman Triathlon, and the Hawaii Bowl, produces a positive and statistically significant estimate. However, it is difficult to say whether the timing of some of these events impacts the estimates. For example, the Hawaii Bowl occurs on Christmas Eve in each year of the sample frame except for 2003, when it was held on December $23^{\text {rd }}$. Our estimate for the intervention seven days prior the Hawaii Bowl suggests that arrivals decrease by nearly 2,800 people, which is a decrease of over ten percent compared to a average December day. However, the timing of the Hawaii Bowl means our intervention term is also a dummy variable for December $17^{\text {th }}$, which may a desire among tourists who plan to be in Hawaii over Christmas to wait until it is closer to the holiday. In addition, the Hawaii Bowl occurs in every year of the sample, and it is possible that arrivals could be even lower in absence of this event.

While the regular timing of the two professional golf events, Ironman Triathlon, and the Hawaii Bowl limits identification of their impacts, the same cannot be said for the Pro Bowl. In comparison, Baumann, Matheson, and Muroi (2009), who use the same empirical technique and data albeit with a much shorter time frame, find positive and statistically significant arrival effects leading up to the Pro Bowl. However, in each year that article’s sample frame (2004 through mid-2008) the Pro Bowl was held in Hawaii during early February. In our sample frame, the Pro Bowl changes months and twice was not played in Hawaii, which allows us to better identify effects from hosting the game. Since we do not find any statistically significant impact from hosting the Pro Bowl, we conclude the positive Pro Bowl effects from Baumann, Matheson, and Muroi (2009) are more likely due to regular spikes in tourism that occur in early February rather a result of 
the Pro Bowl. Either way, whether the marginal effect of the Pro Bowl on arrivals is not statistically distinguishable from zero as suggested by this paper or between 5,596 and 6,726 additional arrivals as estimated by Baumann, Matheson, and Muroi (2009), the benefits of hosting the Pro Bowl do not seem to justify the large direct public payment given to the NFL.

\section{Conclusions}

Cities and states often use spectator sports as a vehicle for economic growth. The HTA is devoted to attracting, and in some cases, financing sporting events in order to increase tourism in the short term and to raise the state's profile. In addition, the HTA routinely provides estimates of the economic impact of the events it subsidizes in order to justify its spending on these events. Compared to other economic impact analyses, Hawaii is a unique location to study economic impact because of (1) the state's remote location, (2) the availability of daily arrival data and the state's remote location, and (3) the variety of sporting events it hosts.

While the HTA estimates that 2014 Pro Bowl produced \$71.9 in direct visitor spending, our analysis of the organization's current methodology for determining economic impact is seriously flawed. Furthermore, an examination of tourist arrivals finds no statistically significant increase in tourism associated with the game. This result fails to justify the \$5 million subsidy, which roughly two-thirds of the HTA’s expenditures on sporting events, it spends for the rights to the Pro Bowl. In comparison, the Hawaii Marathon, which receives no direct funding from the HTA, attracts roughly 3,900 extra tourists. While there are some costs and inconveniences associated with the 
marathon, they are likely to be small in comparison to the Pro Bowl even without the public subsidy necessary to bring the event to Hawaii.

Of course, the power of the NFL to extract higher rents from the HTA than the Honolulu Marathon Association, despite the fact that the race could claim that it brings in a higher number of visitors, should come as no surprise. Unlike the NFL's control over its brand, no single organization can claim a monopoly on the 26.2 mile distance of a marathon. Even though the dollar effect of these sporting events is difficult to quantify, it seems apparent that the Marathon is a bargain compared the large investment necessary to bring the Pro Bowl to Hawaii. 


\section{References}

Associated Press. 2011. "Gov.: Hawaii 'so stupid' to waste money.”

http://sports.espn.go.com/nfl/news/story?id=6645862. Posted June 10, 2011.

Accessed June 10, 2015.

Baade, Robert A., Robert Baumann, and Victor A. Matheson. 2008. Selling the Game:

Estimating the Economic Impact of Professional Sports through Taxable Sales. Southern Economic Journal, Vol. 74:3, 794-810.

Baade, Robert and Victor Matheson. 2001. Home Run or Wild Pitch? Assessing the Economic Impact of Major League Baseball’s All-Star Game. Journal of Sports Economics, 2:4, 307-327.

Baade, Robert A. and Victor A. Matheson. 2004. The Quest for the Cup: Assessing the Economic Impact of the World Cup. Regional Studies, Vol. 38:4, 343-354.

Baade, Robert A. and Victor A. Matheson. 2006. Padding Required: Assessing the Economic Impact of the Super Bowl. European Sports Management Quarterly, Vol. 6:4, 353-374.

Baumann, Robert A., Bryan Engelhardt, and Victor Matheson. 2012. “Employment Effects of the 2002 Winter Olympics in Salt Lake City, Utah,” Journal of Economics and Statistics, Vol. 232:3, 308-317.

Baumann, Robert, Victor Matheson, and Chihiro Muroi. 2009. “Bowling in Hawaii: Examining the Effectiveness of Sports-Based Tourism Strategies,” Journal of Sports Economics, Vol. 10:1, 107-123. 
Box, G. and G. Tiao. 1975. Intervention Analysis with Applications to Economic and Environmental Problems, Journal of the American Statistical Association, Vol. 70, 70-79.

Bureau of Labor Statistics. 2008. State and Area Employment, Hours, and Earnings. www.bls.gov.

Coates, Dennis. 2006. The Tax Benefits of Hosting the Super Bowl and the MLB AllStar Game: The Houston Experience. International Journal of Sports Finance, 1.

Coates, Dennis and Craig A. Depken, II. 2006. Mega-Events: Is the Texas-Baylor game to Waco what the Super Bowl is to Houston? International Association of Sports Economists, Working Paper 06-06.

Coates, Dennis and Brad R. Humphreys. 2002. The Economic Impact of Post-Season Play in Professional Sports. Journal of Sports Economics, 3, 291-299.

Dickey, D. A., and W. A. Fuller. 1979 “Distribution of the Estimators for Autoregressive Time Series With a Unit Root.” Journal of the American Statistical Association, 74: 427-431.

Dickey, D. A., and W. A. Fuller. 1981. "Likelihood Ratio Statistics for Autoregressive Time Series With a Unit Root.” Econometrica, 4(9): 1057-1072.

Fletcher, Dan. 2010. “Is the NFL Pro Bowl Broken?” Time Magazine, http://content.time.com/time/nation/article/0,8599,1957574,00.html. Posted January 29, 2010. Accessed July 29, 2015.

Fouriea, Johan and María Santana-Gallego. 2011. The impact of mega-sport events on tourist arrivals, Tourism Management, Vol. 32:6, 1364-1370. 
Fouriea, Johan and María Santana-Gallego. 2015. How the ‘Hand of Henry’ Benefited the South African Economy, ERSA working paper 508.

Hagn, Florian and Wolfgang Maennig. 2008. Employment effects of the Football World Cup 1974 in Germany, Labour Economics, 15:5, 1062-1075.

Hagn, Florian and Wolfgang Maennig. 2009 Large sport events and unemployment: the case of the 2006 soccer World Cup in Germany, Applied Economics, 41:25, 3295-3302.

Hawaii Tourism Authority. 2014. 2014 Annual Report, www.hawaiitourismauthority.org.

Jasmand, Stephanie and Wolfgang Maennig. 2008. "Regional Income and Employment Effects of the 1972 Munich Olympic Summer Games,” Regional Studies, Vol. 42:7, 991-1002.

Kwiatowski, Denis, Peter C. B. Phillips, Peter Schmidt, and Yongcheoi Shin. 1992.

“Testing the Null Hypothesis of Stationarity against the Alternative of a Unit Root.” Journal of Econometrics, Vol. 54, 159-178.

Lavoie, Marc and Gabriel of Rodriguez. 2005. “The Economic Impact of Professional Teams on Monthly Hotel Occupancy Rates of Canadian Cities: A Box-Jenkins Approach,” Journal of Sports Economics, Vol. 6:3, 314-324.

Lewis, Ferd. 2014. Hawaii and Houston Vie for 2017 Pro Bowl, Honolulu StarAdvertiser, April 12, 2014.

Marvez, Alex. "NFL considering Brazil as host for 2017 Pro Bowl.” Fox Sports. Posted March 23, 2015. Accessed July 29, 2015.

Matheson, Victor A. 2006. The Effects of Labour Strikes on Consumer Demand in Professional Sports: Revisited, Applied Economics, Vol. 38:10, 1173-1179. 
Peeters, Thomas, Victor Matheson, and Stefan Szymanski. 2014. “Tourism and the 2010 World Cup: Lessons for Developing Countries,” Journal of African Economies, Vol. 23:2, 290-320.

Phillips, P. C. B., and P. Perron. 1988. “Teshting for Unit Root in Time Series Regression.” Biometrika 75: 335-346.

Porter, Philip. 1999. Mega-Sports Events as Municipal Investments: A Critique of Impact Analysis. In Fizel, J., Gustafson, E. and Hadley, L. Sports Economics: Current Research. Westport, CT: Praeger Press, 61-74.

Ritchie, J.R. Brent and Brian H. Smith (1991). The Impact Of A Mega-Event On Host Region Awareness: A Longitudinal Study, Journal of Travel Research, 30:1, 3-10.

Schmidt, Martin and David Berri. 2002. The impact of the 1981 and 1994-1995 strikes on Major League Baseball attendance: a time series analysis, Applied Economics, Vol. 34, 471-478.

Shankman, Samantha. 2014. Hawaii Tourism Says it Makes \$88 Million for Every $\$ 5$ Million It Invests in a Pro Bowl, Skift.com, http://skift.com/2014/04/10/hawaiitourism-says-it-makes-88-million-for-every-5-million-it-invests-in-a-pro-bowl. Posted April 10, 2015. Accessed June 1, 2015.

Sports Media Watch. 2013. 2013 Ratings Wrap: NFL Dominates List of Most-Wathed Sporting Events. http://www.sportsmediawatch.com/2013/12/2013-ratings-wrapnfl-dominates-list-of-most-watched-sporting-events. Posted December 31, 2013. Accessed October 31, 2014. 
Teigland, Jon. 1999. Mega-events and impacts on tourism; the predictions and realities of the Lillehammer Olympics, Impact Assessment and Project Appraisal, 17:4, 305317.

Zimbalist, Andrew. 2015. Circus Maximus: The Economic Gamble Behind Hosting the Olympics and the World Cup, Brookings Institution Press. 
Table 1: 2013 Television ratings for selected sporting events

\begin{tabular}{|l|c|c|}
\hline Event & Rating & Viewers (millions) \\
\hline NFL Super Bowl & 46.4 & 108.7 \\
\hline NCAA Football BCS championship & 15.1 & 26.4 \\
\hline NBA Finals - Game 7 & 15.3 & 26.3 \\
\hline NCAA Basketball - Final Four & 14.0 & 23.4 \\
\hline MLB World Series - Game 6 & 11.3 & 19.2 \\
\hline NASCAR Daytona 500 & 9.9 & 16.7 \\
\hline Kentucky Derby & 9.7 & 16.2 \\
\hline Golf: The Masters - Final round & 9.4 & 16.0 \\
\hline NFL Pro Bowl & $\mathbf{7 . 1}$ & $\mathbf{1 2 . 2}$ \\
\hline MLB All-Star Game & 6.9 & 11.0 \\
\hline NHL Stanley Cup Finals - Game 6 & 4.7 & 8.2 \\
\hline NBA All-Star Game & 4.6 & 8.0 \\
\hline Tennis: U.S. Open Final (Women) & 4.0 & 6.2 \\
\hline
\end{tabular}

(Source: Sports Media Watch, 2013) 
Table 2: Event spending by HTA in 2013

\begin{tabular}{|l|c|c|}
\hline Category & Number of events & Total Subsidy \\
\hline Native Hawaiian festivals & 11 & $\$ 513,000$ \\
\hline Other major festivals & 9 & $\$ 883,000$ \\
\hline Signature sporting events & 13 & $\$ 2,034,500$ \\
\hline Pro Bowl & 1 & $\$ 4,152,000$ \\
\hline Total & 34 & $\$ 7,588,500$ \\
\hline
\end{tabular}

(Source: Hawaii Tourism Authority, 2014) 
Table 3: Reported economic impact of Pro Bowl for various years

\begin{tabular}{|l|c|c|c|c|c|}
\hline Year & Attendance & Visitors & $\begin{array}{c}\text { Visitor } \\
\text { Spending }\end{array}$ & $\begin{array}{c}\text { Spending per } \\
\text { visitor }\end{array}$ & Tax revenues \\
\hline 2007 & 50,410 & 27,625 & $\$ 28.0$ mil. & $\$ 1,014$ & $\$ 2.72$ mil. \\
\hline 2008 & & \multicolumn{3}{|c|}{ No event in Hawaii. Pro Bowl held in Miami } \\
\hline 2009 & 49,958 & 24,230 & $\$ 28.6$ mil. & $\$ 1,180$ & $\$ 2.90$ mil. \\
\hline 2011 & 49,338 & 21,204 & $\$ 28.2$ mil. & $\$ 1,333$ & $\$ 3.07$ mil. \\
\hline 2012 & 48,423 & 18,873 & \$25.3 mil. & \$1,341 & \$2.80 mil. \\
\hline 2013 & 47,134 & \multicolumn{3}{|c|}{ Not available. No economic impact report issued. } \\
\hline 2014 & 47,270 & 47,270 & \$71.9 mil. & \$1,521 & n.a. \\
\hline
\end{tabular}

(Source: Various media reports, 2007-2014) 
Table 4: Event Dates

\begin{tabular}{|c|c|c|c|c|c|c|}
\hline & Pro Bowl & $\begin{array}{c}\text { Hawaii } \\
\text { Bowl }\end{array}$ & $\begin{array}{l}\text { Hyundai } \\
\text { Tourn. of } \\
\text { Champ. }\end{array}$ & $\begin{array}{l}\text { Sony } \\
\text { Open }\end{array}$ & $\begin{array}{l}\text { Honolulu } \\
\text { Marathon }\end{array}$ & $\begin{array}{l}\text { Ironman } \\
\text { Triathlon }\end{array}$ \\
\hline 2004 & Feb. 8 & Dec. 24 & Jan. 8-11 & Jan. 15-18 & Dec. 12 & Oct. 16 \\
\hline 2005 & Feb. 13 & Dec. 24 & Jan. 6-9 & Jan. 13-16 & Dec. 11 & Oct. 15 \\
\hline 2006 & Feb. 12 & Dec. 24 & Jan. 5-8 & Jan. 12-15 & Dec. 10 & Oct. 21 \\
\hline 2007 & Feb. 10 & Dec. 23 & Jan. 4-7 & Jan. 11-14 & Dec. 9 & Oct. 13 \\
\hline 2008 & Feb. 10 & Dec. 24 & Jan. 3-6 & Jan. 10-13 & Dec. 14 & Oct. 11 \\
\hline 2009 & Feb. 8 & Dec. 24 & Jan. 8-11 & Jan. 15-18 & Dec. 13 & Oct. 10 \\
\hline 2010 & & Dec. 24 & Jan. 7-10 & Jan. 14-17 & Dec. 12 & Oct. 9 \\
\hline 2011 & Jan. 30 & Dec. 24 & Jan. 6-9 & Jan. 13-16 & Dec. 11 & Oct. 8 \\
\hline 2012 & Jan. 29 & Dec. 24 & Jan. 6-9 & Jan. 12-15 & Dec. 9 & Oct. 13 \\
\hline 2013 & Jan. 27 & Dec. 24 & Jan. 4-8 & Jan. 10-13 & Dec. 8 & Oct. 12 \\
\hline 2014 & Jan. 26 & Dec. 24 & Jan. 3-6 & Jan. 9-12 & Dec. 14 & Oct. 11 \\
\hline 2015 & & & Jan. 9-12 & Jan. 15-18 & & \\
\hline
\end{tabular}

Note: The sample frame is January 3, 2004 to May 31, 2015, which is before the 2015 versions of the Hawaii Bowl, Honolulu Marathon, and Ironman Triathlon. The 2010 and 2015 versions of the Pro Bowl were not held in Hawaii. Finally, the Hyundai Tournament of Champions has also been called the SBS Championship (2010), Mercedes-Benz Championship (2007 to 2009), and Mercedes Championships (2004 to 2006). 
Figure 1: Mean Daily Arrivals by Day

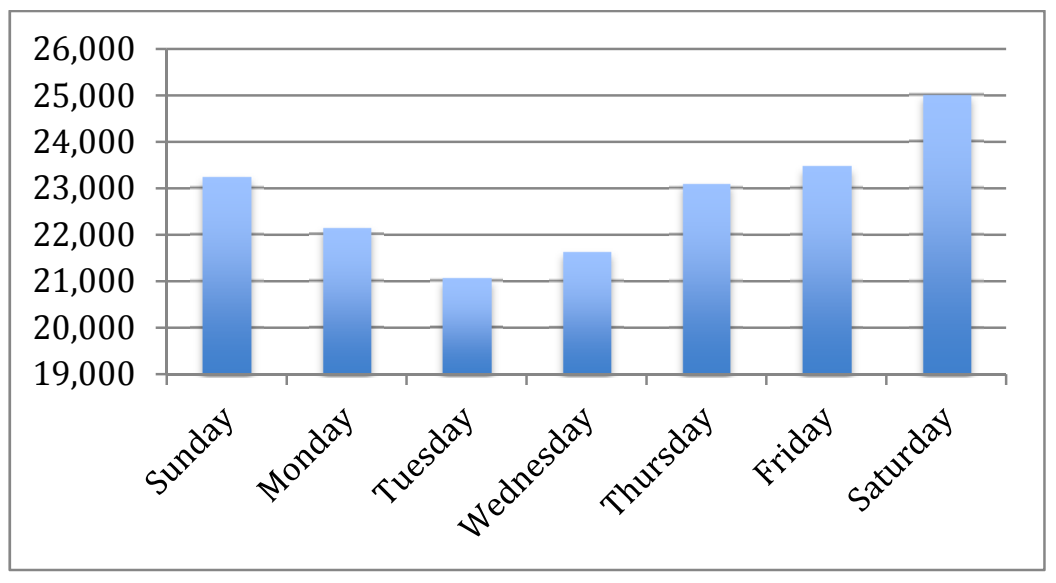

Figure 2: Mean Daily Arrivals by Month

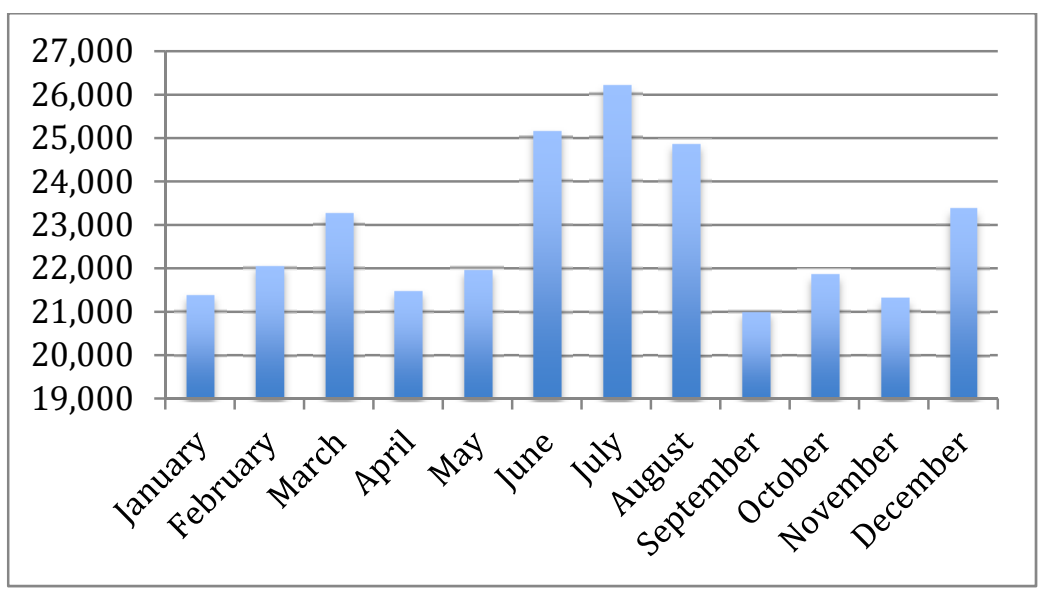

Figure 3: Mean Daily Arrivals by Year

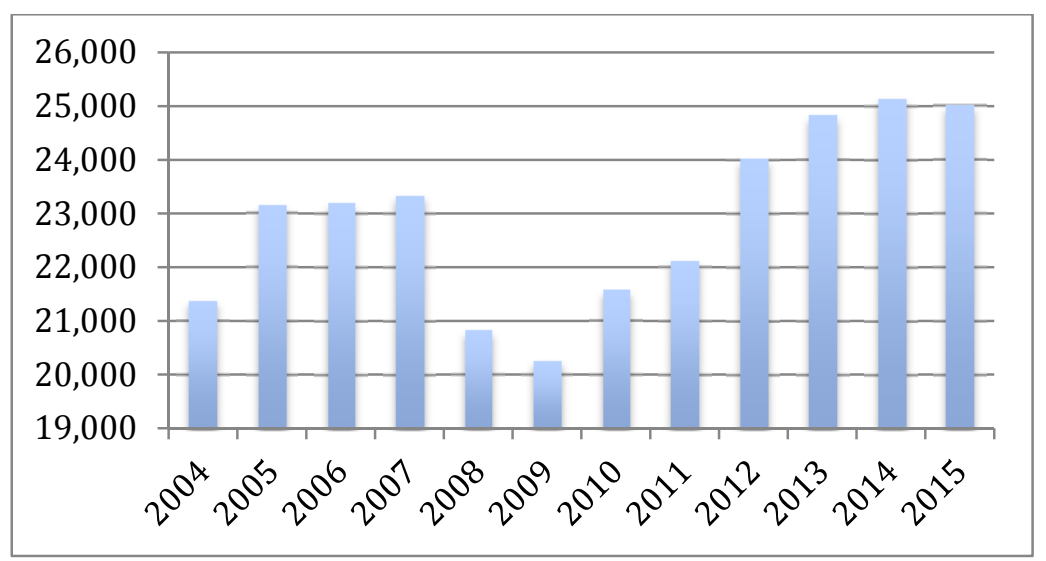

Note: The sample mean for all arrivals is about 22,817 and the standard deviation is about 3,256. The sample frame is from January 3, 2004 to May 31, 2015. 
Figure 4: Daily Arrivals

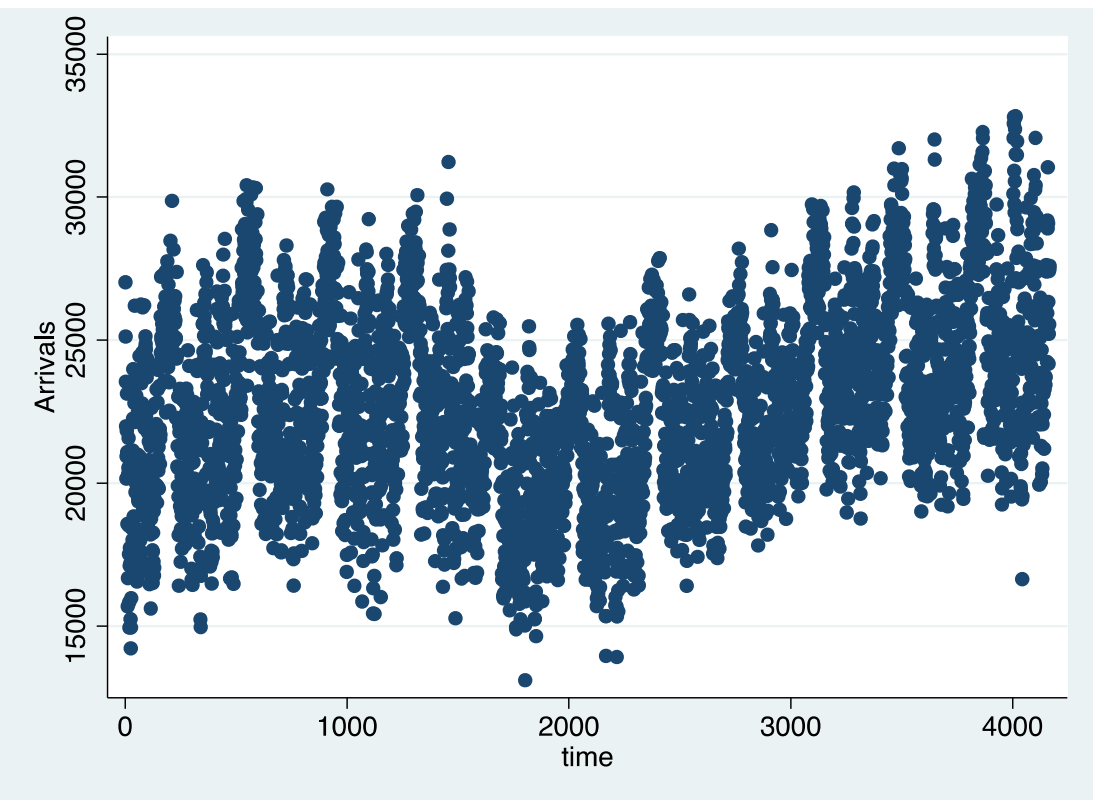

Figure 5: Daily Residual Arrivals

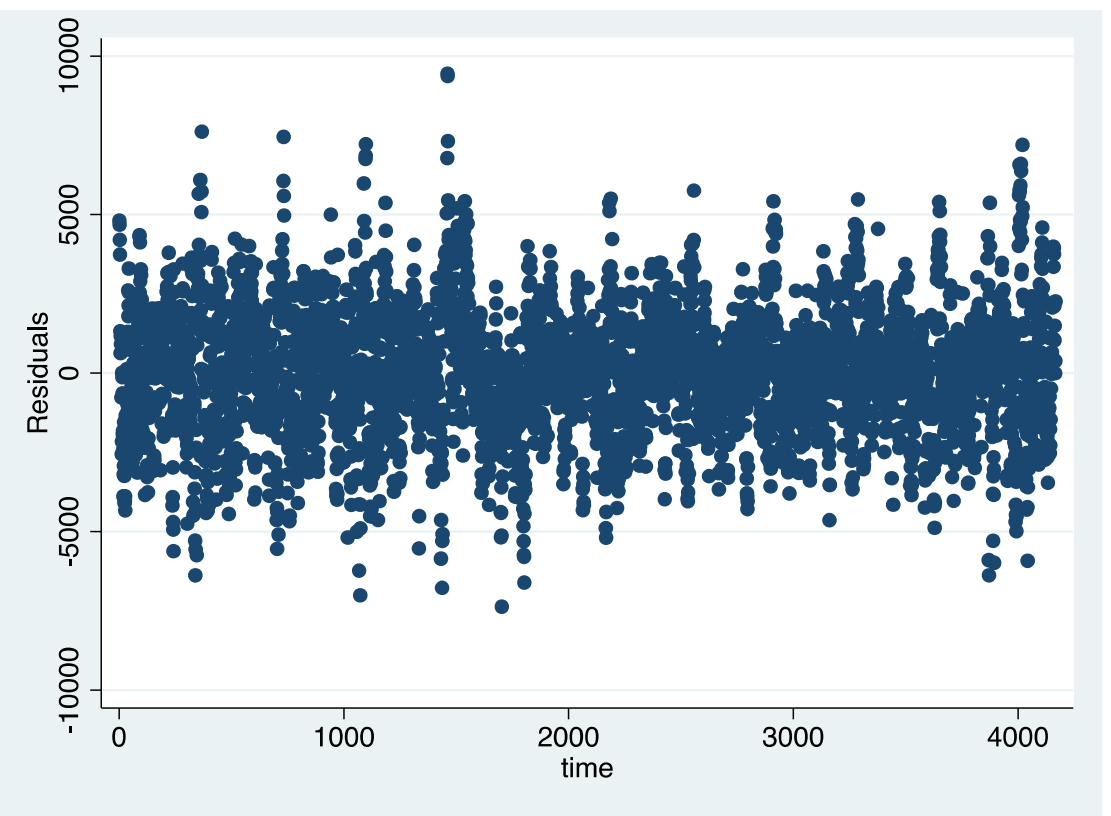

Note: Time runs from 1, which is January 3, 2004, to 4,167, which is May 31, 2015. Residual arrivals are the error terms from a regression of actual arrivals on dummy variables for each day of the week, month, and year in the sample frame. 
Table 5: Unit Root Test Statistics of Residual Arrivals ( $p$-values in parentheses)

\begin{tabular}{|c|c|c|c|c|}
\hline Lags & $\begin{array}{c}\text { Augmented } \\
\text { Dickey-Fuller }\end{array}$ & $\begin{array}{c}\text { GLS } \\
\text { Dickey-Fuller }\end{array}$ & Phillips-Perron & $\begin{array}{c}\text { Kwiatkowski- } \\
\text { Phillips- } \\
\text { Schmidt-Shin }\end{array}$ \\
\hline 1 & $\begin{array}{c}-20.068 \\
(p<0.0001)\end{array}$ & $\begin{array}{c}-11.885 \\
(p<0.01)\end{array}$ & $\begin{array}{c}-22.070 \\
(p<0.0001)\end{array}$ & $\begin{array}{c}0.119 \\
(p>0.1)\end{array}$ \\
\hline 2 & $\begin{array}{c}-18.764 \\
(p<0.0001)\end{array}$ & $\begin{array}{c}-10.833 \\
(p<0.01)\end{array}$ & $\begin{array}{c}-21.975 \\
(p<0.0001)\end{array}$ & $\begin{array}{c}0.086 \\
(p>0.1)\end{array}$ \\
\hline 3 & -16.515 & $\begin{array}{c}-9.355 \\
(p<0.01)\end{array}$ & $\begin{array}{c}-21.730 \\
(p<0.0001)\end{array}$ & $\begin{array}{c}0.069 \\
(p>0.1)\end{array}$ \\
\hline 4 & -14.560 & -8.171 & -21.536 & 0.059 \\
$(p>0.0001)$ & $(p<0.01)$ & -7.716 & -21.602 & $0.1)$ \\
\hline 5 & -13.918 & $(p<0.01)$ & $(p<0.0001)$ & $(p>0.1)$ \\
\hline
\end{tabular}

Note: The null hypothesis in augmented Dickey-Fuller and Phillips-Perron testing is a unit root, whereas the null hypothesis in Kwiatkowski-Phillips-Schmidt-Shin is a stationary series. 
Table 6: Results

(Standard Errors in Parentheses)

\begin{tabular}{|c|c|c|c|}
\hline $\begin{array}{c}\text { Pro Bowl, } \\
\text { one day prior }\end{array}$ & $\begin{array}{c}-782.0^{* *} \\
(376.8)\end{array}$ & $\begin{array}{c}\text { Honolulu Marathon, } \\
\text { one day prior }\end{array}$ & $\begin{array}{c}9.7 \\
(292.6)\end{array}$ \\
\hline Pro Bowl, & -123.0 & $\begin{array}{c}\text { Honolulu Marathon, } \\
\text { two days prior }\end{array}$ & $533.6^{*}$ \\
two days prior & $(334.2)$ & $298.6)$ \\
\hline Pro Bowl, & -123.8 & Honolulu Marathon, & 32.9 \\
three days prior & $(326.6)$ & $(363.6)$ \\
\hline Pro Bowl, & 175.3 & Honolulus prior & four days prior \\
four days prior & $(367.3)$ & $1,013.5^{* * *}$ & $(347.0)$ \\
\hline Pro Bowl, & 44.8 & Honolulu Marathon, & $993.2^{* * *}$ \\
five days prior & $(345.2)$ & five days prior & $(364.0)$ \\
\hline Pro Bowl, & 341.7 & Honolulu Marathon, & $729.4^{* *}$ \\
\hline six days prior & $(330.7)$ & six days prior & $(350.0)$ \\
\hline Pro Bowl, & 72.3 & Honolulu Marathon, & $625.4^{* *}$ \\
seven days prior & $(303.1)$ & seven days prior & $(276.4)$ \\
\hline Golf Event, & -278.3 & Ironman, & 146.6 \\
one day prior & $(255.5)$ & one day prior & $(347.4)$ \\
\hline Golf Event, & 134.6 & Ironman, & 305.4 \\
two days prior & $(271.2)$ & two days prior & $(510.1)$ \\
\hline Golf Event, & $-1,017.7^{* * *}$ & Ironman, & 436.7 \\
three days prior & $(235.2)$ & three days prior & $(537.2)$ \\
\hline Golf Event, & -163.4 & Ironman, & -327.5 \\
four days prior & $(235.0)$ & four days prior & $(559.3)$ \\
\hline Golf Event, & $-526.4^{*}$ & Ironman, & -504.3 \\
five days prior & $(271.1)$ & five days prior & $(535.2)$ \\
\hline Golf Event, & 125.9 & Ironman, & -438.2 \\
six days prior & $(249.2)$ & six days prior & $(505.9)$ \\
\hline Golf Event, & -172.9 & Ironman, & 112.6 \\
seven days prior & $(249.7)$ & seven days prior & $(410.1)$ \\
\hline & & & \\
\hline & & & \\
\hline
\end{tabular}

Note: Dummy variables for each year, month and day of the week are included but not presented here. In addition, ${ }^{*},{ }^{* *}$, and ${ }^{* * *}$ represent statistical significance at the ten, five, and one percent thresholds, respectively. 
Table 6: Results Continued (Standard Errors in Parentheses)

\begin{tabular}{|c|c|}
\hline $\begin{array}{l}\text { Hawaii Bowl, } \\
\text { one day prior }\end{array}$ & $\begin{array}{l}-197.2 \\
(349.0)\end{array}$ \\
\hline $\begin{array}{l}\text { Hawaii Bowl, } \\
\text { two days prior }\end{array}$ & $\begin{array}{c}164.4 \\
(341.4)\end{array}$ \\
\hline $\begin{array}{l}\text { Hawaii Bowl, } \\
\text { three days prior }\end{array}$ & $\begin{array}{l}-481.8 \\
(412.6)\end{array}$ \\
\hline $\begin{array}{l}\text { Hawaii Bowl, } \\
\text { four days prior }\end{array}$ & $\begin{array}{c}240.8 \\
(407.6) \\
\end{array}$ \\
\hline $\begin{array}{l}\text { Hawaii Bowl, } \\
\text { five days prior }\end{array}$ & $\begin{array}{c}480.3 \\
(410.4)\end{array}$ \\
\hline $\begin{array}{l}\text { Hawaii Bowl, } \\
\text { six days prior }\end{array}$ & $\begin{array}{l}-576.4 \\
(372.5)\end{array}$ \\
\hline $\begin{array}{l}\text { Hawaii Bowl, } \\
\text { seven days prior }\end{array}$ & $\begin{array}{c}-2,787.0^{* * * *} \\
(322.0)\end{array}$ \\
\hline $\mathrm{AR}(1)$ & $\begin{array}{l}0.763^{* * *} \\
(0.013)\end{array}$ \\
\hline $\mathrm{AR}(2)$ & $\begin{array}{l}0.054^{* * * *} \\
(0.017)\end{array}$ \\
\hline AR(3) & $\begin{array}{c}0.022 \\
(0.018)\end{array}$ \\
\hline $\mathrm{AR}(4)$ & $\begin{array}{l}0.053^{* * * *} \\
(0.018)\end{array}$ \\
\hline $\mathrm{AR}(5)$ & $\begin{array}{l}0.070^{* * * *} \\
(0.018)\end{array}$ \\
\hline AR(6) & $\begin{array}{l}-0.007 \\
(0.019)\end{array}$ \\
\hline AR(7) & $\begin{array}{l}0.251^{* * *} \\
(0.018)\end{array}$ \\
\hline $\mathrm{AR}(8)$ & $\begin{array}{c}-0.225^{* * *} \\
(0.014)\end{array}$ \\
\hline log Likelihood & $-35,069.998$ \\
\hline
\end{tabular}

Note: Dummy variables for each year, month and day of the week are included but not presented here. In addition, ${ }^{*},{ }^{* *}$, and ${ }^{* * *}$ represent statistical significance at the ten, five, and one percent thresholds, respectively. 